\title{
Mechanical Properties of Pack Carburized SCM 420 Steel Processed Using Natural Shell Powders and Extended Carburization Time
}

\author{
Ramli $^{1}$, Chung-Chun Wu ${ }^{1, *}$ and Adel Shaaban ${ }^{2}$ (D) \\ 1 Mechanical Engineering Department, Southern Taiwan University of Science and Technology, \\ Tainan 71005, Taiwan; ramli.barmawi83@gmail.com \\ 2 National Center for Radiation Research (NCRRT), Department of Radiation Engineering, Atomic Energy \\ Authority, Cairo 11765, Egypt; engadelsas@gmail.com \\ * Correspondence: wcc@stust.edu.tw
}

check for updates

Citation: Ramli; Wu, C.-C.; Shaaban,

A. Mechanical Properties of Pack

Carburized SCM 420 Steel Processed

Using Natural Shell Powders and

Extended Carburization Time.

Crystals 2021, 11, 1136. https://

doi.org/10.3390/cryst11091136

Academic Editor: Cyril Cayron

Received: 12 July 2021

Accepted: 15 September 2021

Published: 18 September 2021

Publisher's Note: MDPI stays neutral with regard to jurisdictional claims in published maps and institutional affiliations.

Copyright: (c) 2021 by the authors. Licensee MDPI, Basel, Switzerland. This article is an open access article distributed under the terms and conditions of the Creative Commons Attribution (CC BY) license (https:// creativecommons.org/licenses/by/ $4.0 /)$.

\begin{abstract}
The feasibility of using coconut shell powder (CSP) and dog conch shell powder (DCSP) as carburizing media in the pack carburization of SCM 420 steel was investigated. The carbon content and surface hardness of the carburized specimens prepared with different CSP:DCSP ratios and carburizing durations were examined and compared. A CSP:DCSP ratio of 60\%:40\% and an extended carburizing time of $12 \mathrm{~h}$ were found to increase the carbon content of the carburized specimens to $1.14 \pm 0.007 \mathrm{wt} \%$. Furthermore, the surface hardness was significantly improved to $961.3 \pm 4.918 \mathrm{HV}$ following water quenching. Finally, the thickness of the carburized layer of the quenched specimens increased by around 2.5 times as the carburizing duration was increased from 3 to $12 \mathrm{~h}$.
\end{abstract}

Keywords: packed carburization; dog conch shell; carburizing time; activated carbon; hardness; carbon content

\section{Introduction}

Low-to-medium-carbon steels, such as SCM 420, have excellent ductility and high toughness, and are therefore used to manufacture many automobile components, such as racks and gears, shafts, pinions, cams, rockers, axles, valves, and so on [1-4]. However, lowcarbon steels have low hardness and poor mechanical strength. Consequently, in real-world applications, surface treatment is commonly applied to ensure that the components reach the necessary performance standards. Traditional heat-treatment methods fail to yield a significant improvement in the strength and hardness of low-carbon steel components. Thus, induction hardening, cold-working, immersion hardening, and case carburizing are generally preferred [5-7]. Among these methods, case carburizing is particularly effective and is thus one of the most commonly used [8]. In the pack carburization process, the components are packaged into a carbon powder box and heated at a temperature higher than a certain critical value to prompt the diffusion of carbon atoms into the component surface. The carburized component is then either left to cool naturally in the furnace, or is removed from the furnace and quenched in water. The finished component has an extremely high surface hardness while retaining the natural toughness and ductility of the original material in the core $[9,10]$. Importantly, the material properties of the component can be tuned by adjusting the time and temperature of the carburizing process [11-14]. Generally speaking, a longer carburizing time and a higher temperature result in a thicker carbon diffusion layer and hence a greater surface hardness [15-18].

Many different materials can be used as the carbon source in the pack carburizing process, including barium carbonate $\left(\mathrm{BaCO}_{3}\right)$, sodium carbonate $\left(\mathrm{NaCO}_{3}\right)$, and charcoal [19-25] In addition, various shells and bones have been considered as the energizing source for carburization. For example, Darmo et al. [26] performed the pack carburization of SS400 steel cylinders using teak wood charcoal and Pomacea Canalikulata Lamarck (PCL) shell 
powder as the carbon source and energizing medium, respectively. The results showed that the addition of PCL shell power yielded an effective increase in the hardness of the SS400 components. Soenoko et al. [27] also used PCL shell powder to energize the carburization of SS400 steel components and found that the fatigue strength of the final components could be enhanced through tempering and then quenching the carburized parts in $30 \% \mathrm{NaCl}$ solution. Aramide et al. [28] found that the addition of pulverized bone as an energizer improved both the impact resistance and the stiffness of carburized mild steel specimens. Negara and Widiyarta [29] performed the pack carburization of low carbon steel using goat bone charcoal (GBC) or bamboo charcoal (BC) as the carburizing medium. The results showed that a significant improvement in the hardness, tensile strength, yield strength, and elastic modulus could be obtained given an appropriate choice of carburizer (i.e., GBC or BC). Miswanto et al. [30] significantly improved the carbon content of low-carbon steel by utilizing a combination of cow bone and coconut shell charcoal as carburizing media.

The feasibility of using seafood shells as energizing sources for the packed carburization process has received considerable attention in recent years. Seafood shells are generally treated as garbage. Therefore, reusing them as an energizing source in the carburization process has significant environmental benefits. In a previous study [31], the present group showed that the addition of dog conch shell powder (DCSP) improved the carbon content of SCM 420 from $0.221 \mathrm{wt} \%$ to $0.647 \mathrm{wt} \%$ given a carburizing temperature of $950{ }^{\circ} \mathrm{C}$ and a DCSP content of $40 \%$. Moreover, the surface hardness increased from $165.61 \pm 4.67 \mathrm{HV}$ to $850.10 \pm 4.84 \mathrm{HV}$ following quenching. However, the study only considered a carburizing duration of $3 \mathrm{~h}$. Therefore, the present study investigated the elemental composition, microhardness, microstructure, and carbon diffusion layer thickness of SCM 420 specimens carburized using DCSP and coconut shell powder (CSP) for durations of 3, 6, and $12 \mathrm{~h}$, respectively. For each carburizing experiment, the carburizing temperature was fixed as $950{ }^{\circ} \mathrm{C}$ and the DCSP content was set in the range of $10-50 \%$. Following the carburization process, the specimens were allowed to cool naturally in the furnace. Some of the samples were then reheated to $950{ }^{\circ} \mathrm{C}$ for $10 \mathrm{~min}$ and then quenched in water to investigate the effect of the quenching process on the hardness of the samples.

\section{Materials and Methods}

The carburizing trials were performed using SCM 420 steel bars with a length and diameter of $50 \mathrm{~mm}$ and $20 \mathrm{~mm}$, respectively. The samples were placed in a low-carbon steel carburizing box with dimensions of $240 \times 120 \times 80 \mathrm{~mm}^{3}$ (length $\times$ width $\times$ height) and a thickness of $5 \mathrm{~mm}$. The experiments were conducted using CSP:DCSP percentage ratios of 100\%:0\%, 90\%:10\%, 80\%:20\%, 70\%:30\%, 60\%:40\% and 50\%:50\%, respectively. In each experiment, the specified quantity of carburizing media (CSP and DCSP) was added to the box and the box was then placed in an electric furnace and heated at $950{ }^{\circ} \mathrm{C}$ for 3,6 , and $12 \mathrm{~h}$. To prevent oxidation, nitrogen gas was circulated continuously through the furnace during the entire carburization process. The specimens were allowed to cool naturally to room temperature in the electric furnace after the carburizing process. To investigate the effect of quenching on the microhardness of the carburized specimens, all carburized specimens were re-heated at a temperature of $950{ }^{\circ} \mathrm{C}$ for $10 \mathrm{~min}$ and then rapidly coo in water.

The carburized and quenched samples were machined into test pieces and polished with a motor-driven disk grinder and polisher to a certain surface roughness. Microhardness measurements were carried out using a Vickers hardness testing machine (Wilson Hardness, Tukon 1102, China) under a $1 \mathrm{kgf}$ load. To ensure the reliability of the measurement results, the hardness was measured five times (using a new sample each time) for every experimental condition. The five measurement results were then averaged to obtain a representative value for the sample. The chemical compositions of the carburizing media were identified by Scanning Electron Microscopy (SEM) machine (Hitachi S-3000N, Tokyo, Japan) with a detector energy dispersive spectroscopy (EDS) (X-maxN20, Horiba Ltd., Tokyo, Japan). The activated carbon made of coconut shell powders (CSP) from 
the company was washed with distilled water repeatedly to remove the contaminants and then dried in a furnace at $60^{\circ} \mathrm{C}$ overnight. Before being powdered, the dog conch shell was immersed in a 10\% H2SO4 solution for $6 \mathrm{~h}$, then washed with distilled water repeatedly and dried in an oven for $24 \mathrm{~h}$ at $60^{\circ} \mathrm{C}$ to remove any impurities. In addition, the carbon content of the various SCM 420 carburized and quenched samples was analyzed using glow discharge spectrometry (GDS) (Leco-GDS500A, Michigan, MI, USA). Before performing GDS analysis, all samples were ground with 120-grit ZrO2 pape to smooth out the surface and washed in alcohol, then dried with an air compressor to remove any surface impurities. Again, to ensure the reliability of GDS analysis results, the carbon content was measured three times per sample (five samples for each carburizing condition), and was then averaged to find a representative value for each experimental condition. Furthermore, the carbon content value distributed within the carburized layer of the quenched specimen was also measured three times per depth carburizing layer of $100 \mu \mathrm{m}$. The phase compositions of the carburizing media and treated specimens were examined by X-ray diffractometry (XRD) (Bruker D2 Phaser, Karlsruhe, Germany) using a diffraction angle range of $20-80^{\circ}$ and $\mathrm{CuK} \alpha$ radiation. Finally, the microstructures of the specimens were observed by optical microscopy (Olympus BX51M, Tokyo, Japan).

\section{Results and Discussion}

\subsection{Phase and Chemical Composition of Carburizing Media and Specimens}

The EDS analysis results for the chemical composition of the CSP and DCSP used as carburizing media in the pack carburizing experiments are shown in Figures 1 and 2. Three different spectrum areas were detected to analyzed chemical compositions for each carburizing medium. From Figure 1, the EDS analysis revealed that the carbon element was present in a higher amount than $\mathrm{Ca}$ and $\mathrm{O}$ elements. This result indicated that CSP particle is mainly made of carbon. Furthermore, referring to the EDS results presented in Figure 2, it is seen that the $100 \%$ DCSP also consists of Ca, C, and O elements. However, the amount of carbon element is lower than $\mathrm{Ca}$ and $\mathrm{O}$. Figure 3 presents the XRD results for the CSP and DCSP media. The XRD patterns reveal that the pure CSP (i.e., 100\% CSP) had an amorphous carbon (C) structure. This result is consistent with XRD patterns of graphitic carbon for FeGC1100 non-catalyst sample [32], and also XRD results of activated carbon from rubber fruit shell using $\mathrm{KOH}$ activation [33]. The pure DCSP (i.e., 100\% DCSP) had an orthorhombic aragonite $\left(\mathrm{CaCO}_{3}\right)$ structure [34]. Notably, the orthorhombic aragonite phase persisted even after mixing the DCSP with CSP in various quantities (i.e., 90\%:10\%, 80\%:20\%, 70\%:30\%, 60\%:40\% and 50\%:50\%, respectively), as shown in Figure 4 [31]. However, the peak position of the aragonite $\mathrm{CaCO} 3$ shifted slightly to the right as the DCSP concentration increased.

Figure 5 shows the XRD analysis results for the original SCM 420 raw material and the carburized samples prepared using a CSP:DCSP ratio of 60\%:40\% and carburizing durations of 3,6 , and $12 \mathrm{~h}$, respectively. (Note that for the carburized samples, XRD patterns are presented for both the as carburized samples and the quenched samples.) As shown, the original SCM 420 raw material had a high Fe-intensity peak and a body-centered cubic (BCC) crystal structure. The carburized SCM 420 specimens consisted predominantly of Fe and $\mathrm{Fe}_{3} \mathrm{C}$ phases with a BCC and orthorhombic crystal structure, respectively. Finally, the quantity of $\mathrm{Fe}_{3} \mathrm{C}$ phase increased following the quenching process, particularly in the specimens carburized for a longer duration. The presence of $\left(\mathrm{Fe}_{3} \mathrm{C}\right)$ carbides on the quenched specimens was pointed out by SEM/EDS observations, as illustrated in Figures 6 and 7. From Figure 6, it can be clearly seen that some $\mathrm{Fe}_{3} \mathrm{C}$ carbides existed in the carburized and diffusion layers of the specimen. Figure 7 shows the EDS analysis results of quenched specimens in different areas. Base on EDS results, some particles were enriched in carbon elements, showing that these particles were $\mathrm{Fe}_{3} \mathrm{C}$ carbides. This result is consistent with the result of the XRD analysis depicted in Figure 5. 

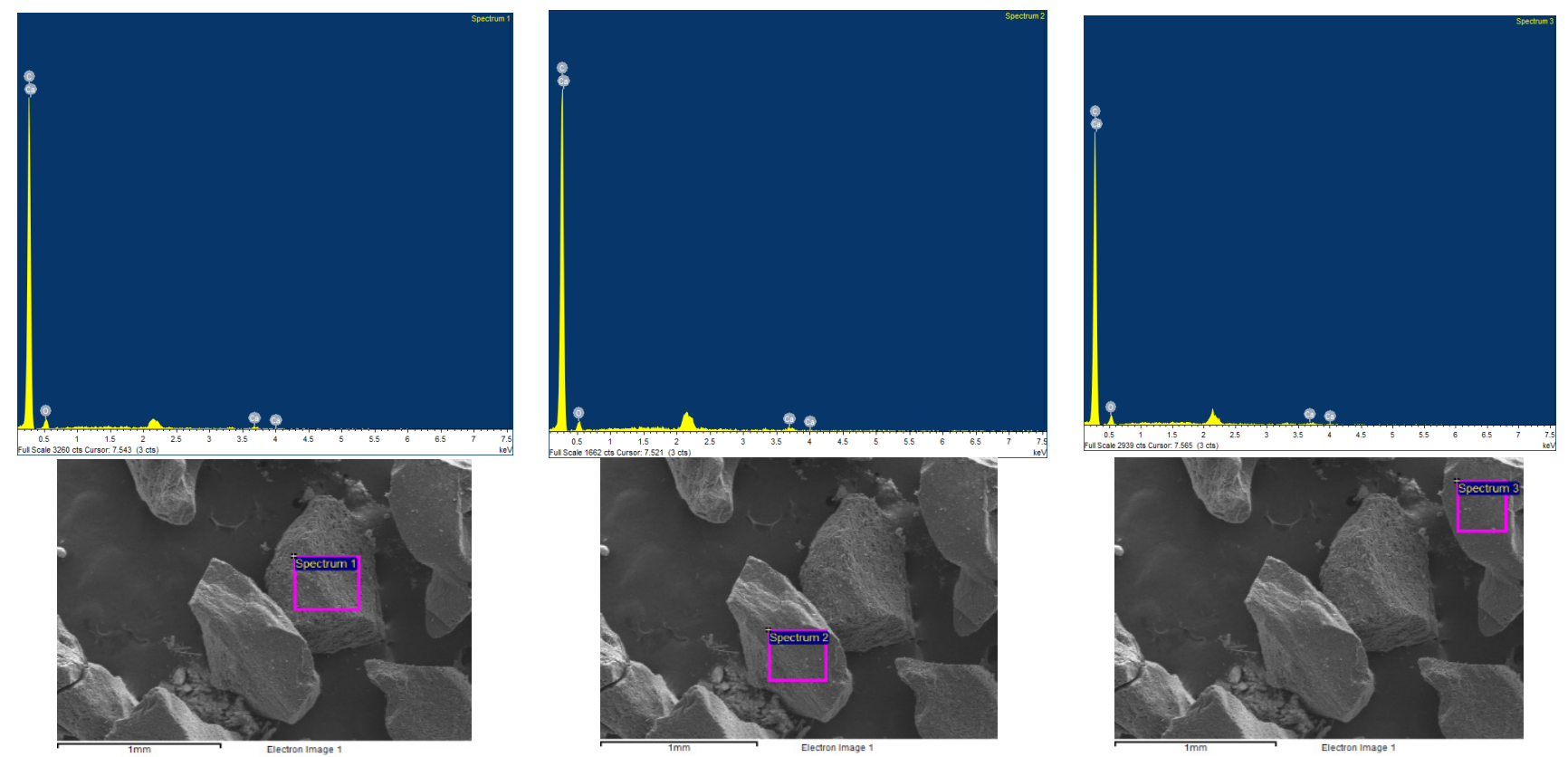

Figure 1. EDS analysis results for CSP.
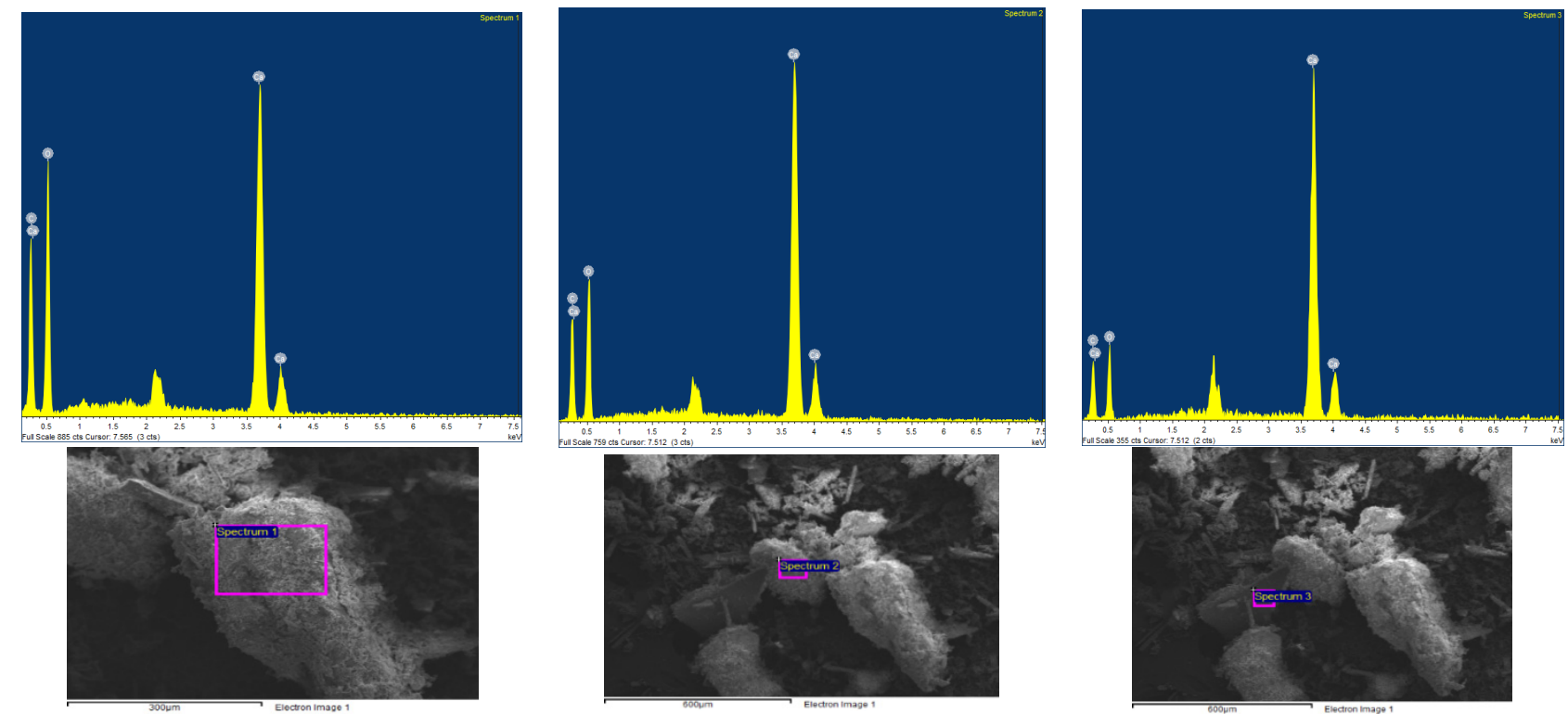

Figure 2. EDS analysis results for DCSP. 


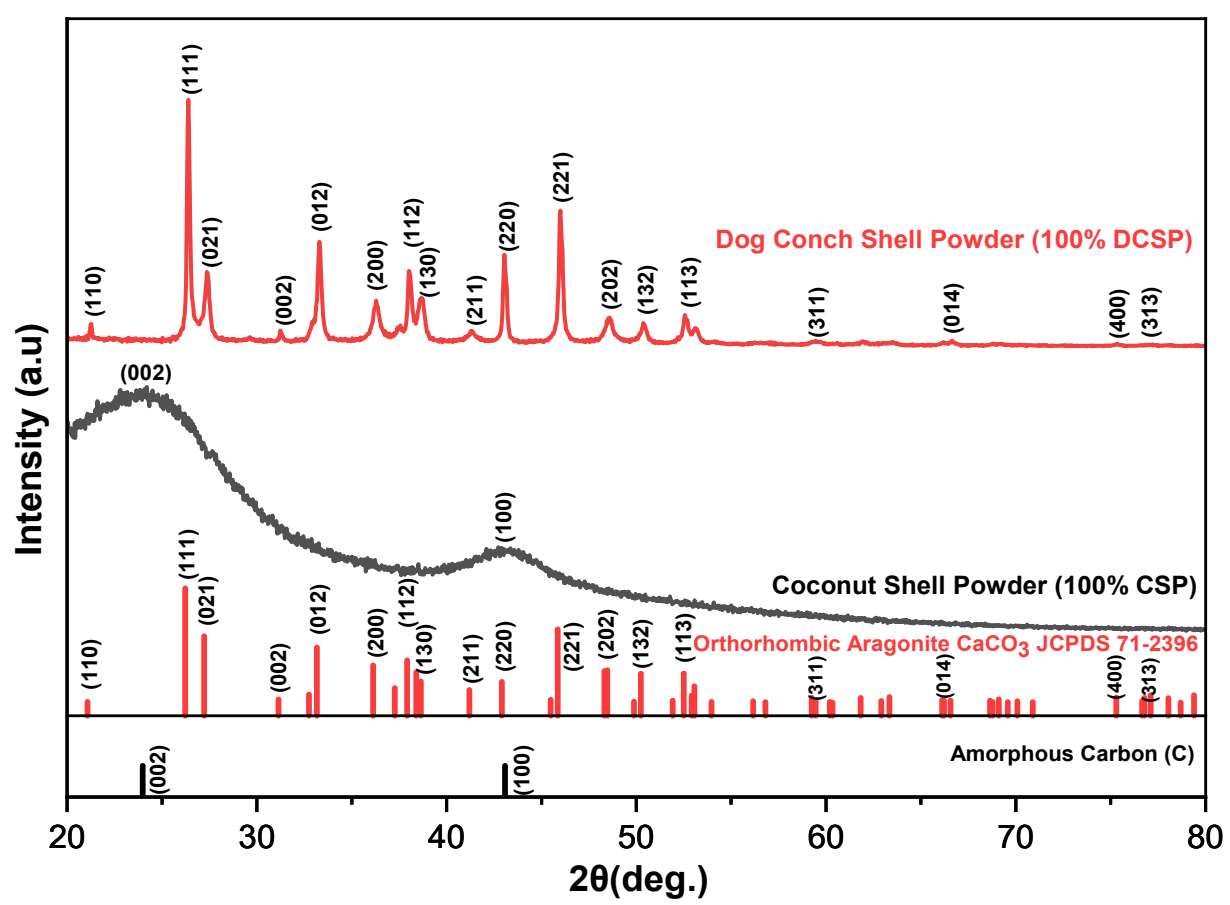

Figure 3. XRD analysis results for pure CSP and DCSP.

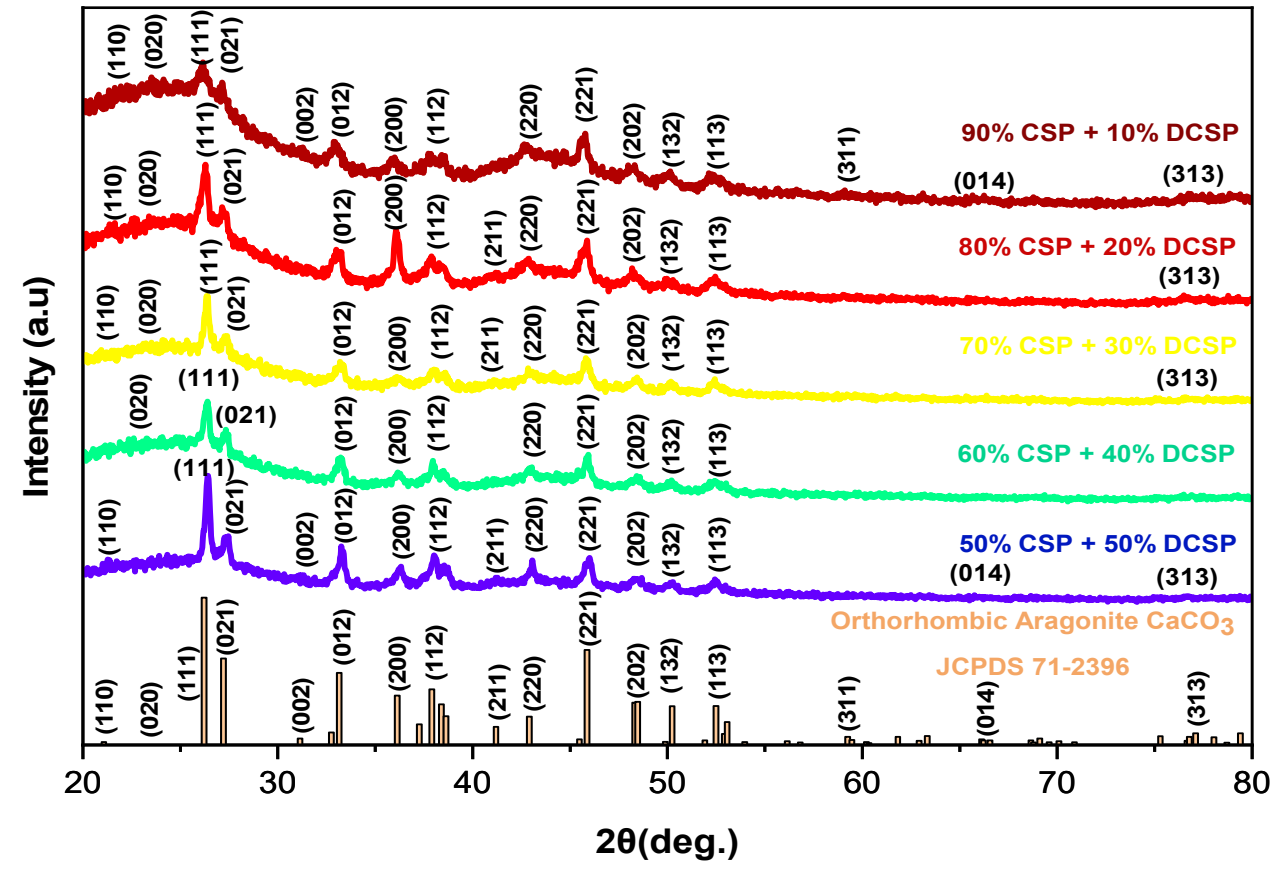

Figure 4. XRD analysis results for various CSP:DCSP ratios "Reprinted from [31] under the CC BY license". 


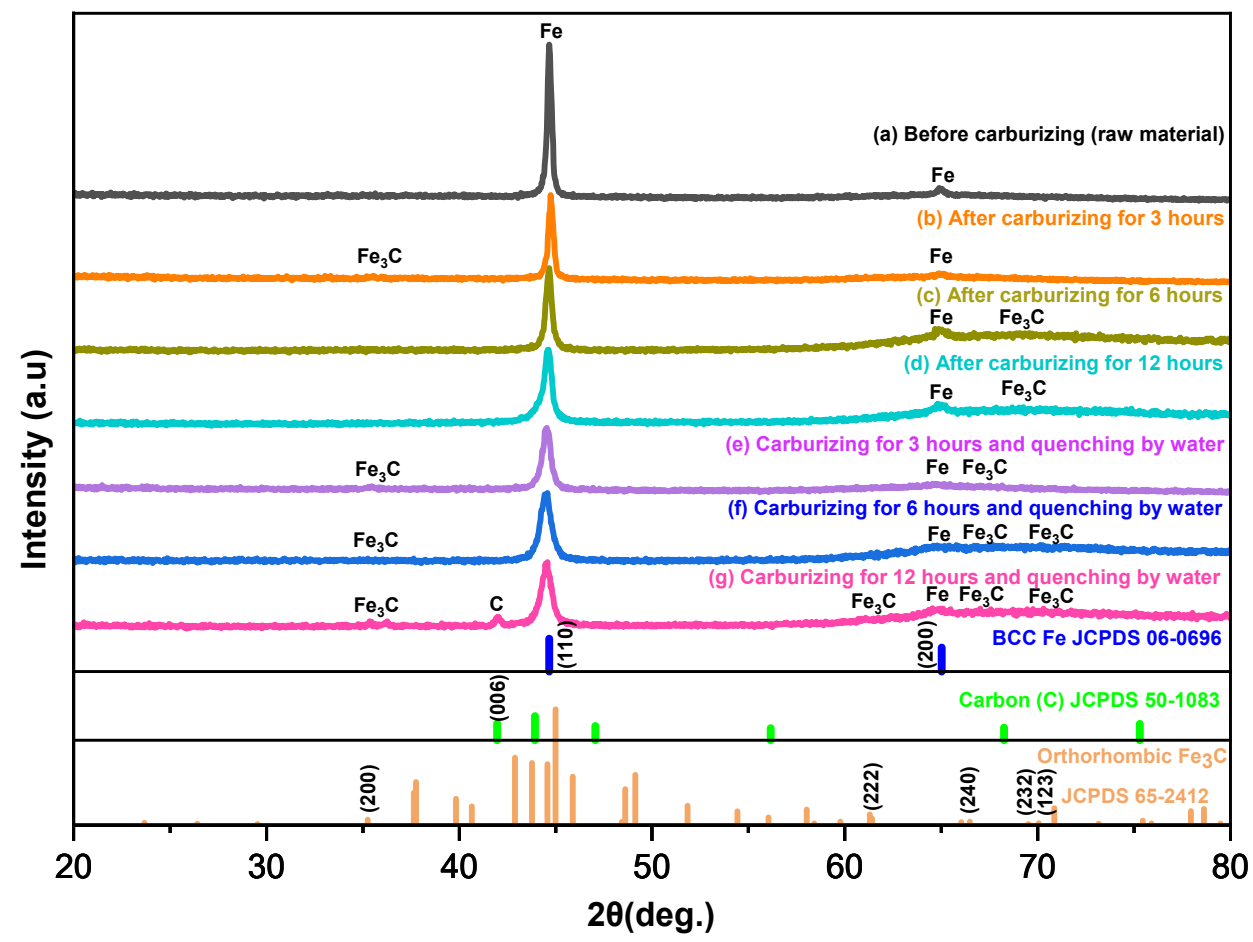

Figure 5. XRD analysis results for original SCM 420 raw material and carburized and quenched SCM 420 specimens prepared with a CSP:DCSP ratio of 60\%:40\% and carburizing durations of 3, 6 , and $12 \mathrm{~h}$.

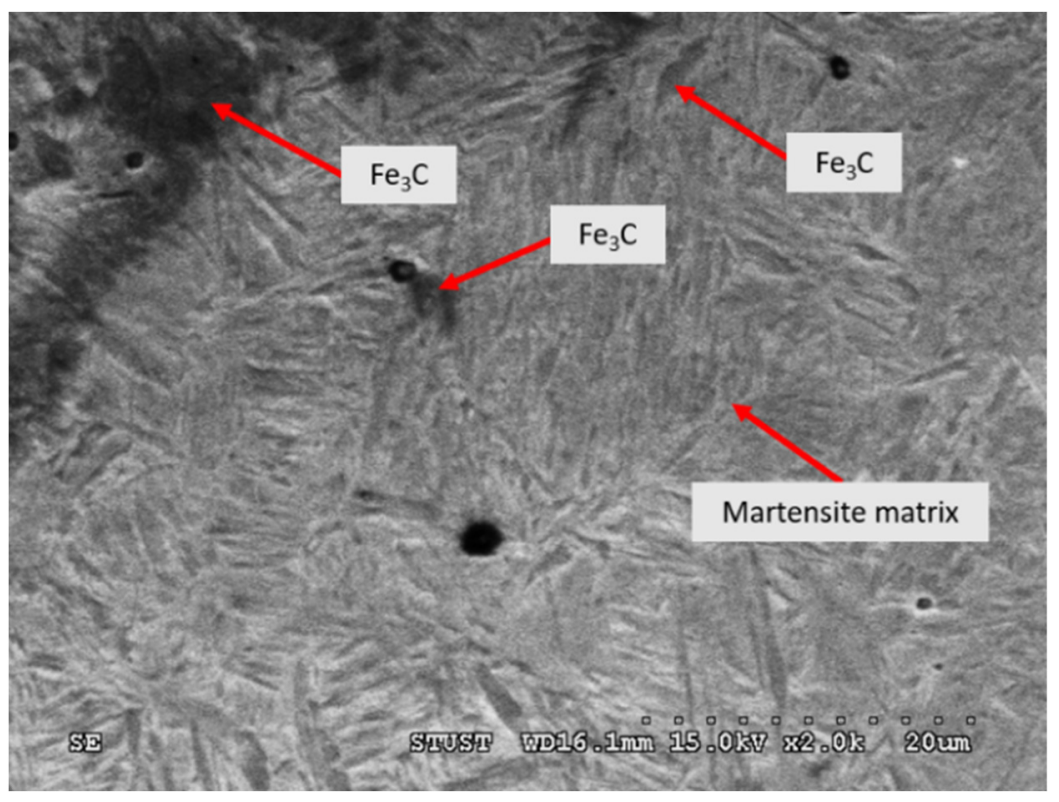

Figure 6. The SEM micrograph of quenched specimens carburized using a CSP:DCSP ratio of $60 \%: 40 \%$ and a carburizing time of $12 \mathrm{~h}$. 


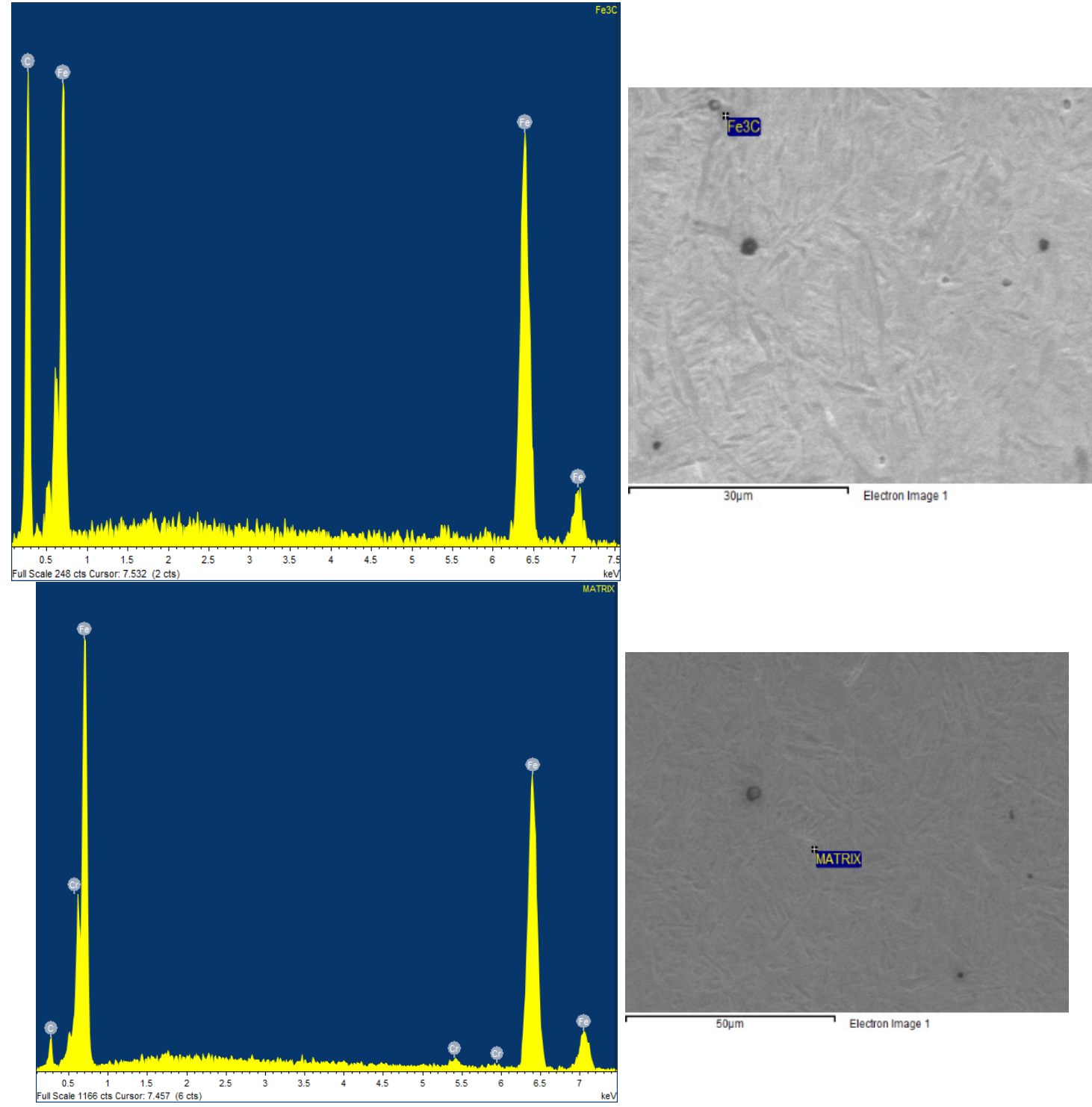

Figure 7. EDS analysis result on the different areas of quenched specimens carburized with a CSP:DCSP ratio of $60 \%: 40 \%$ and a carburizing time of $12 \mathrm{~h}$.

Table 1 shows the lattice constant values of various phases for different carburizing media concentrations shown in Figures 3 and 4. For each concentration, a gap existed between the standard and calculated values of the lattice constants. Moreover, the magnitude of the gap varied with the CSP/DCSP ratio. From inspection, the minimal gap occurred for the sample with a CSP:DCSP ratio of $60 \%: 40 \%$, which indicates that the aragonite $\left(\mathrm{Ca}^{-} \mathrm{CO}_{3}\right)$ phases for this particular CSP:DCSP ratio were more stable than those for other CSP:DCSP concentrations. Table 2 shows the standard and calculated lattice constant values of the SCM 420 base material, carburized specimens, and quenched specimens shown in Figure 5. Generally speaking, a good agreement was observed between the standard and calculated lattice constant values in every case. Hence, it is inferred that all of the phases formed in the various specimens were relatively stable. 
Table 1. Lattice constants of various phases for different carburizing media concentrations.

\begin{tabular}{|c|c|c|c|c|}
\hline JCPDS & $\begin{array}{c}\text { Relative Concentration of } \\
\text { Carburizing Media }\end{array}$ & Lattice Constant & $\begin{array}{c}\text { Standard } \\
\text { Values ( } \AA \text { ) }\end{array}$ & Calculated Values (Å) \\
\hline \multirow{18}{*}{$\begin{array}{c}\text { Orthorhombic } \\
\text { Aragonite }\left(\mathrm{CaCO}_{3}\right) \\
\text { JCPDS } 71-2396\end{array}$} & \multirow{3}{*}{$100 \%$ DCSP } & $\mathrm{a}$ & 4.961 & 4.946 \\
\hline & & $\mathrm{b}$ & 7.970 & 7.884 \\
\hline & & c & 5.739 & 5.717 \\
\hline & \multirow{3}{*}{ CSP:DCSP ratio of $90 \%: 10 \%$} & $\mathrm{a}$ & 4.961 & 4.998 \\
\hline & & $\mathrm{b}$ & 7.970 & 7.937 \\
\hline & & c & 5.739 & 5.430 \\
\hline & \multirow{3}{*}{ CSP:DCSP ratio of $80 \%: 20 \%$} & a & 4.961 & 4.972 \\
\hline & & $\mathrm{b}$ & 7.970 & 7.921 \\
\hline & & $\mathrm{c}$ & 5.739 & 5.917 \\
\hline & \multirow{3}{*}{ CSP:DCSP ratio of 70\%:30\% } & $\mathrm{a}$ & 4.961 & 4.967 \\
\hline & & $\mathrm{b}$ & 7.970 & 7.909 \\
\hline & & c & 5.739 & 5.704 \\
\hline & \multirow{3}{*}{ CSP:DCSP ratio of $60 \%: 40 \%$} & a & 4.961 & 4.960 \\
\hline & & $\mathrm{b}$ & 7.970 & 7.981 \\
\hline & & c & 5.739 & 5.765 \\
\hline & \multirow{3}{*}{ CSP:DCSP ratio of $50 \%: 50 \%$} & a & 4.961 & 4.951 \\
\hline & & $\mathrm{b}$ & 7.970 & 7.897 \\
\hline & & c & 5.739 & 5.382 \\
\hline
\end{tabular}

Table 2. Lattice constants of various phases in original SCM 420 steel; carburized samples with a CSP:DCSP ratio of $60 \%: 40 \%$ and carburizing durations of 3,6 and $12 \mathrm{~h}$, respectively; and quenched specimens.

\begin{tabular}{|c|c|c|c|c|}
\hline Specimen & JCPDS & Lattice Constant & Standard Values (Å) & Calculated Values ( $($ ) \\
\hline Original SCM 420 raw material & $\begin{array}{l}\text { Body centered cubic Iron, syn } \\
\text { (Fe) JCPDS 6-696 }\end{array}$ & $\mathrm{a}=\mathrm{b}=\mathrm{c}$ & 2.886 & 2.870 \\
\hline \multirow{2}{*}{$\begin{array}{c}\text { SCM } 420 \text { carburized specimens with } \\
40 \% \text { DCSP for } 3 \mathrm{~h}\end{array}$} & $\begin{array}{l}\text { Body centered cubic Iron, syn } \\
\text { (Fe) JCPDS 6-696 }\end{array}$ & $\mathrm{a}=\mathrm{b}=\mathrm{c}$ & 2.886 & 2.865 \\
\hline & $\begin{array}{l}\text { Orthorhombic Iron carbide } \\
\left(\mathrm{Fe}_{3} \mathrm{C}\right) \mathrm{JCPDS} 65-2412\end{array}$ & $\begin{array}{l}\mathrm{a} \\
\mathrm{b} \\
\mathrm{c}\end{array}$ & $\begin{array}{l}5.089 \\
6.743 \\
4.523\end{array}$ & $\begin{array}{l}5.029 \\
6.601 \\
4.564\end{array}$ \\
\hline \multirow{2}{*}{$\begin{array}{c}\text { SCM } 420 \text { carburized specimens with } \\
40 \% \text { DCSP for } 6 \mathrm{~h}\end{array}$} & $\begin{array}{l}\text { Body centered cubic Iron, syn } \\
\text { (Fe) JCPDS 6-696 }\end{array}$ & $\mathrm{a}=\mathrm{b}=\mathrm{c}$ & 2.886 & 2.870 \\
\hline & $\begin{array}{l}\text { Orthorhombic Iron carbide } \\
\left(\mathrm{Fe}_{3} \mathrm{C}\right) \mathrm{JCPDS} 65-2412\end{array}$ & $\begin{array}{l}\mathrm{a} \\
\mathrm{b} \\
\mathrm{c}\end{array}$ & $\begin{array}{l}5.089 \\
6.743 \\
4.523\end{array}$ & $\begin{array}{l}5.044 \\
6.684 \\
4.526 \\
\end{array}$ \\
\hline \multirow{2}{*}{$\begin{array}{c}\text { SCM } 420 \text { carburized specimens with } \\
40 \% \text { DCSP for } 12 \mathrm{~h}\end{array}$} & $\begin{array}{l}\text { Body centered cubic Iron, syn } \\
\text { (Fe) JCPDS 6-696 }\end{array}$ & $\mathrm{a}=\mathrm{b}=\mathrm{c}$ & 2.886 & 2.874 \\
\hline & $\begin{array}{l}\text { Orthorhombic Iron carbide } \\
\left(\mathrm{Fe}_{3} \mathrm{C}\right) \mathrm{JCPDS} 65-2412\end{array}$ & $\begin{array}{l}\mathrm{a} \\
\mathrm{b} \\
\mathrm{c}\end{array}$ & $\begin{array}{l}5.089 \\
6.743 \\
4.523\end{array}$ & $\begin{array}{l}5.043 \\
6.670 \\
4.526\end{array}$ \\
\hline \multirow{2}{*}{$\begin{array}{l}\text { SCM } 420 \text { carburized specimens with } \\
40 \% \text { DCSP for } 3 \mathrm{~h} \text { after quenching }\end{array}$} & $\begin{array}{l}\text { Body centered cubic Iron, syn } \\
\text { (Fe) JCPDS 6-696 }\end{array}$ & $\mathrm{a}=\mathrm{b}=\mathrm{c}$ & 2.886 & 2.848 \\
\hline & $\begin{array}{l}\text { Orthorhombic Iron carbide } \\
\left(\mathrm{Fe}_{3} \mathrm{C}\right) \mathrm{JCPDS} 65-2412\end{array}$ & $\begin{array}{l}\mathrm{a} \\
\mathrm{b} \\
\mathrm{c}\end{array}$ & $\begin{array}{l}5.089 \\
6.743 \\
4.523\end{array}$ & $\begin{array}{l}5.076 \\
6.712 \\
4.501\end{array}$ \\
\hline \multirow{2}{*}{$\begin{array}{l}\text { SCM } 420 \text { carburized specimens with } \\
40 \% \text { DCSP for } 6 \mathrm{~h} \text { after quenching }\end{array}$} & $\begin{array}{l}\text { Body centered cubic Iron, syn } \\
\text { (Fe) JCPDS 6-696 }\end{array}$ & $\mathrm{a}=\mathrm{b}=\mathrm{c}$ & 2.886 & 2.887 \\
\hline & $\begin{array}{l}\text { Orthorhombic Iron carbide } \\
\left(\mathrm{Fe}_{3} \mathrm{C}\right) \mathrm{JCPDS} 65-2412\end{array}$ & $\begin{array}{l}\mathrm{a} \\
\mathrm{b} \\
\mathrm{c}\end{array}$ & $\begin{array}{l}5.089 \\
6.743 \\
4.523\end{array}$ & $\begin{array}{l}5.112 \\
6.921 \\
4.557\end{array}$ \\
\hline \multirow{3}{*}{$\begin{array}{l}\text { SCM } 420 \text { carburized specimens with } \\
40 \% \text { DCSP for } 12 \mathrm{~h} \text { after quenching }\end{array}$} & $\begin{array}{l}\text { Body centered cubic Iron, syn } \\
\text { (Fe) JCPDS 6-696 }\end{array}$ & $\mathrm{a}=\mathrm{b}=\mathrm{c}$ & 2.886 & 2.848 \\
\hline & Carbon (C) JCPDS 50-1083 & $\begin{array}{l}\mathrm{a} \\
\mathrm{c}\end{array}$ & $\begin{array}{l}2.522 \\
12.35 \\
\end{array}$ & $\begin{array}{c}2.497 \\
12.201 \\
\end{array}$ \\
\hline & $\begin{array}{l}\text { Orthorhombic Iron carbide } \\
\left(\mathrm{Fe}_{3} \mathrm{C}\right) \mathrm{JCPDS} 65-2412\end{array}$ & $\begin{array}{l}\mathrm{a} \\
\mathrm{b} \\
\mathrm{c}\end{array}$ & $\begin{array}{l}5.089 \\
6.743 \\
4.523\end{array}$ & $\begin{array}{l}5.061 \\
6.654 \\
4.526\end{array}$ \\
\hline
\end{tabular}


Table 3 shows the average grain size of the SCM 420 raw material; carburized SCM 420 samples with a CSP:DCSP ratio of $60 \%: 40 \%$ and carburizing durations of 3, 6, and $12 \mathrm{~h}$, respectively; and quenched SCM 420 samples. Note that the grain size was determined directly from the FWHM data of the corresponding XRD patterns shown in Figure 5. It is seen that the original SCM 420 material had an average grain size of $14.54 \pm 0.09 \mu \mathrm{m}$, while the carburized samples processed for 3,6 and $12 \mathrm{~h}$ had average grain sizes of $12.71 \pm 0.11$, $10.18 \pm 0.13$ and $6.57 \pm 0.07 \mu \mathrm{m}$, respectively. After quenching, the average grain size reduced further to $7.76 \pm 0.10,5.97 \pm 0.09$, and $5.72 \pm 0.12 \mu \mathrm{m}$, respectively. Overall, the results show that the carburizing and quenching processes both led to a grain refinement effect. Furthermore, a significant reduction in the grain size also occurred as the carburizing duration increased.

Table 3. The average grain size of original SCM 420 raw material; carburized samples with a CSP:DCSP ratio of $60 \%: 40 \%$ and carburizing durations of 3, 6, and $12 \mathrm{~h}$, respectively; and quenched samples.

\begin{tabular}{cc}
\hline Specimen & Average Grain Size D $(\mu \mathrm{m})$ \\
\hline Original SCM 420 raw material & $14.54 \pm 0.09$ \\
SCM 420 carburized specimens with 40\% DCSP for 3 h & $12.71 \pm 0.11$ \\
SCM 420 carburized specimens with 40\% DCSP for 6 h & $10.18 \pm 0.13$ \\
SCM 420 carburized specimens with 40\% DCSP for 12 h & $6.57 \pm 0.07$ \\
SCM 420 carburized specimens with 40\% DCSP for 3 h after quenching & $7.76 \pm 0.10$ \\
SCM 420 carburized specimens with 40\% DCSP for 6 h after quenching & $5.97 \pm 0.09$ \\
SCM 420 carburized specimens with 40\% DCSP for 12 h after quenching & $5.72 \pm 0.12$ \\
\hline
\end{tabular}

Table 4 shows the chemical composition of the original SCM 420 material. It is seen that the sample had a carbon content of $0.221 \mathrm{wt} \%$ [31]. Figure 8 shows the carbon contents of the carburized samples prepared with various CSP:DCSP ratios and carburizing durations. For each carburizing time, the samples prepared using only CSP as the carburizing medium exhibited the lowest carbon content. By contrast, the samples prepared with a CSP:DCSP ratio of $60 \%: 40 \%$ exhibited the highest carbon content, irrespective of the carburizing duration applied. In general, the results presented in Figure 8 show that as the stability of the $\mathrm{CaCO}_{3}$ phase increased, its effectiveness as an energizer also increased (see Table 1). The results additionally show that for all values of the CSP:DCSP ratio, the carbon content increased with an increasing carburizing time. The maximum carbon content $(1.14 \pm 0.007 \mathrm{wt} \%)$ was that obtained in the SCM 420 sample treated with a CSP:DCSP ratio of $60 \%: 40 \%$ and a carburizing duration of $12 \mathrm{~h}$. It is noted that this value is approximately 1.76 times higher than that obtained in a previous study $(0.647 \pm 0.008 \mathrm{wt} \%)$ with a lower carburizing time of just $3 \mathrm{~h}$ [31]. Moreover, it is also around 1.46 times higher than that obtained in another previous study $(0.78 \mathrm{wt} \%)$ using 30\% PCL shell powder and a carburizing time of $7 \mathrm{~h} \mathrm{[26]}$.

Table 4. Chemical composition of original SCM 420 raw material. "Reprinted from [31] under the CC BY license".

\begin{tabular}{ccccccccccc}
\hline Specimen & $\mathbf{C}$ & $\mathbf{S i}$ & $\mathbf{M n}$ & $\mathbf{P}$ & $\mathbf{S}$ & $\mathbf{C r}$ & $\mathbf{N i}$ & $\mathbf{M o}$ & $\mathbf{C u}$ & $\mathbf{F e}$ \\
\hline $\begin{array}{c}\text { Raw material of } \\
\text { SCM 420 Steel }\end{array}$ & 0.221 & 0.248 & 0.641 & 0.012 & 0.013 & 0.947 & 0.048 & 0.140 & 0.063 & Bal. \\
\hline
\end{tabular}




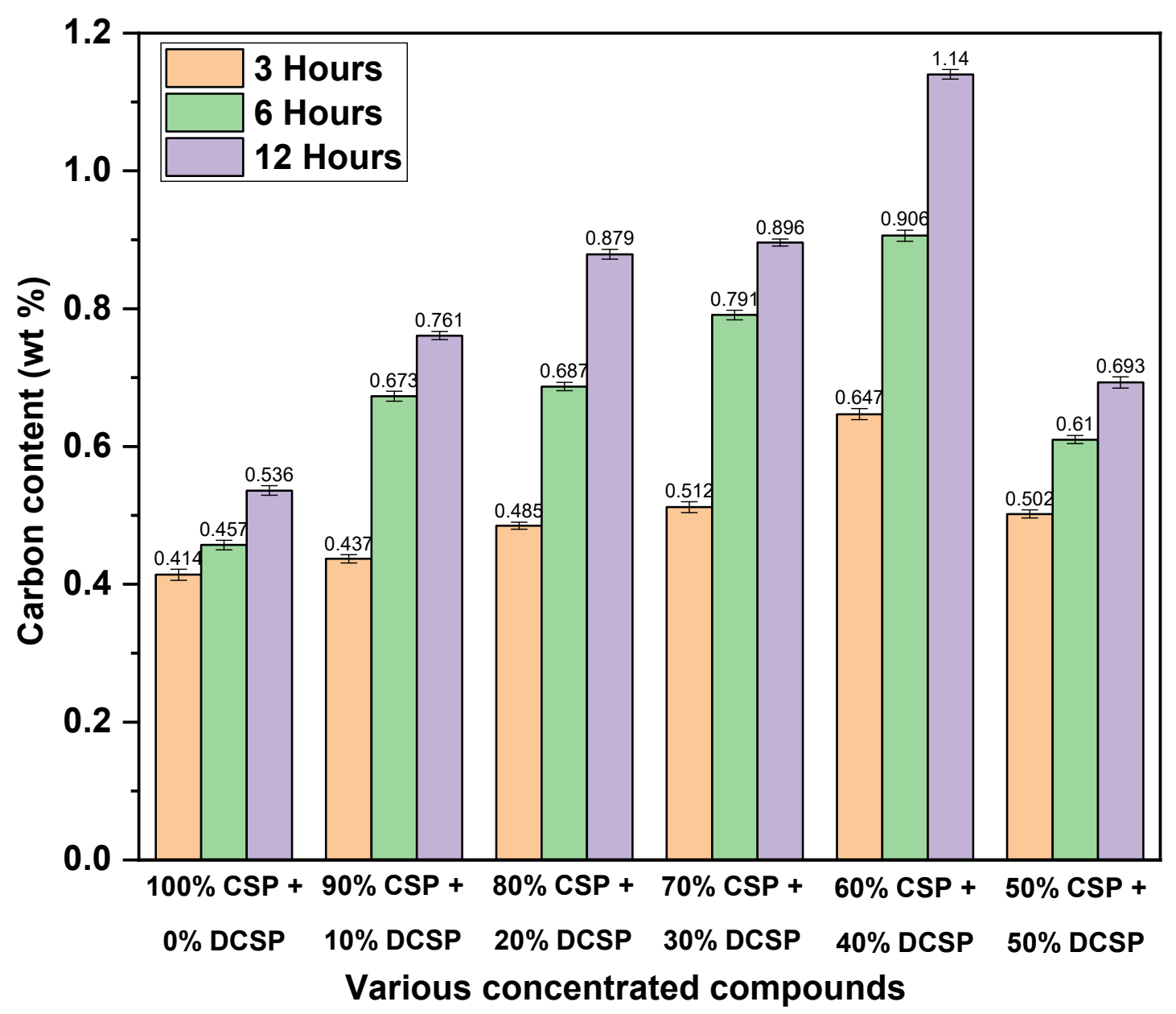

Figure 8. The average carbon content of SCM 420 steel specimens with various CSP:DCSP ratios and carburizing durations.

\subsection{Surface Hardness of Carburized and Quenched SCM 420 Specimens}

Figure 9 presents the surface hardness values of the SCM 420 carburized samples prepared with various CSP:DCSP concentrations and carburizing durations of 3, 6, and $12 \mathrm{~h}$, respectively. Figure 10 shows the equivalent results for the samples reheated to a temperature of $950{ }^{\circ} \mathrm{C}$ for $10 \mathrm{~min}$ and then quenched in water. For both types of the specimen (i.e., carburized and quenched), the hardness increased as the DCSP concentration increased from $10-40 \%$. However, the hardness reduced as the DCSP concentration was further increased to $50 \%$. Moreover, the hardness also increased with an increasing carburizing time. For the non-quenched samples, the maximum hardness was around $604.9 \pm 4.674 \mathrm{HV}$ (CSP:DCSP ratio: 60\%:40\%; carburizing time: $12 \mathrm{~h}$ ). It is approximately 1.72 times higher than that obtained in a previous study $(352.70 \pm 4.96 \mathrm{HV})$ with a lower carburizing time of $3 \mathrm{~h}$ [31]. This result related to the quantity of pearlite on the microstructure of SCM 420 steel-carburized specimen attained with a carburizing time of $12 \mathrm{~h}$ is more than that obtained with carburizing times of 6 and $3 \mathrm{~h}$, respectively, as illustrated in Figure 11. Comparing the results presented in Figure 9; Figure 10, it is seen that the quenching process resulted in a significant improvement in the hardness of all the samples. For example, the surface hardness of the optimal sample in Figure 9 (CSP:DCSP ratio: 60\%:40\%; carburizing time: $12 \mathrm{~h}$ ) increased from $604.9 \pm 4.674 \mathrm{HV}$ in the as-carburized condition to $961.3 \pm 4.918 \mathrm{HV}$ in the quenched condition. 


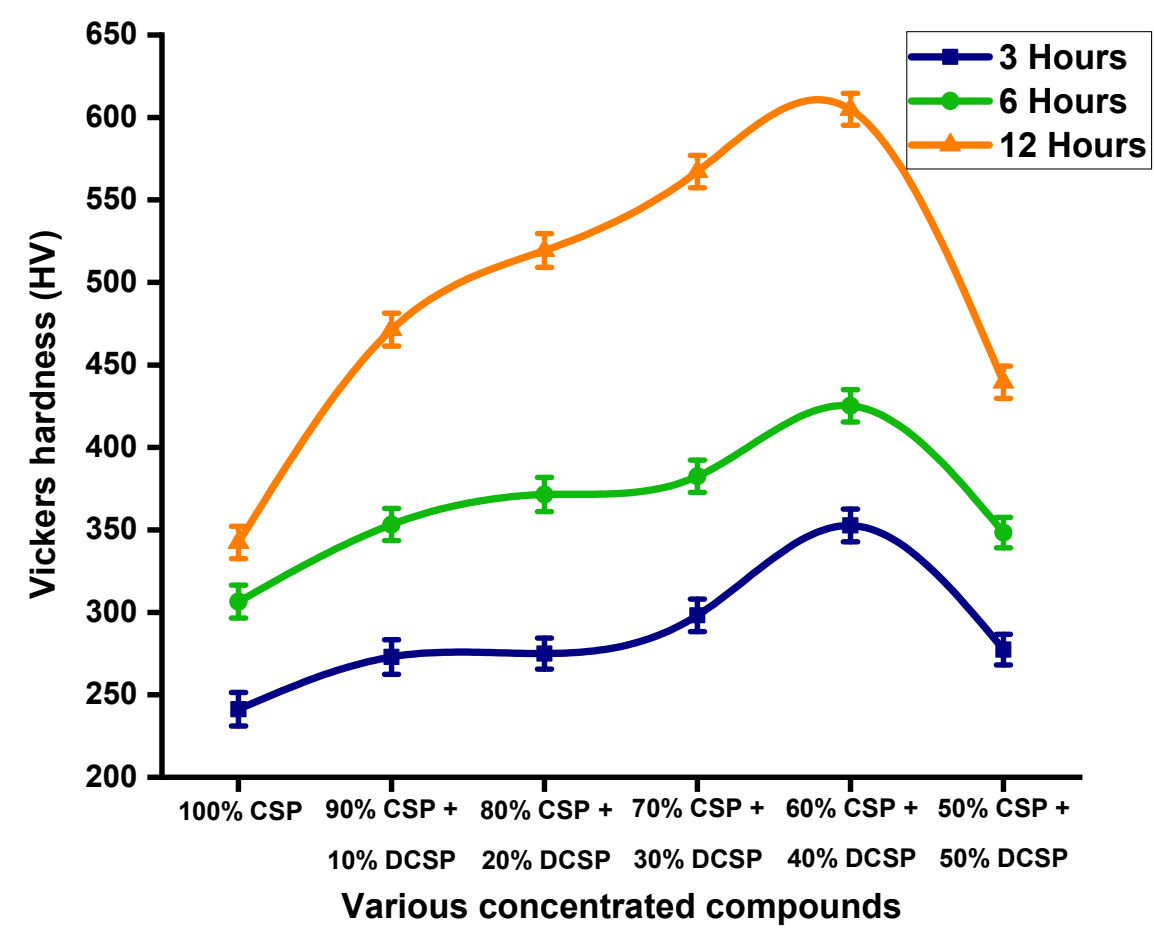

Figure 9. Surface hardness of SCM 420 steel-carburized specimens prepared with various CSP:DCSP ratios and carburizing times.

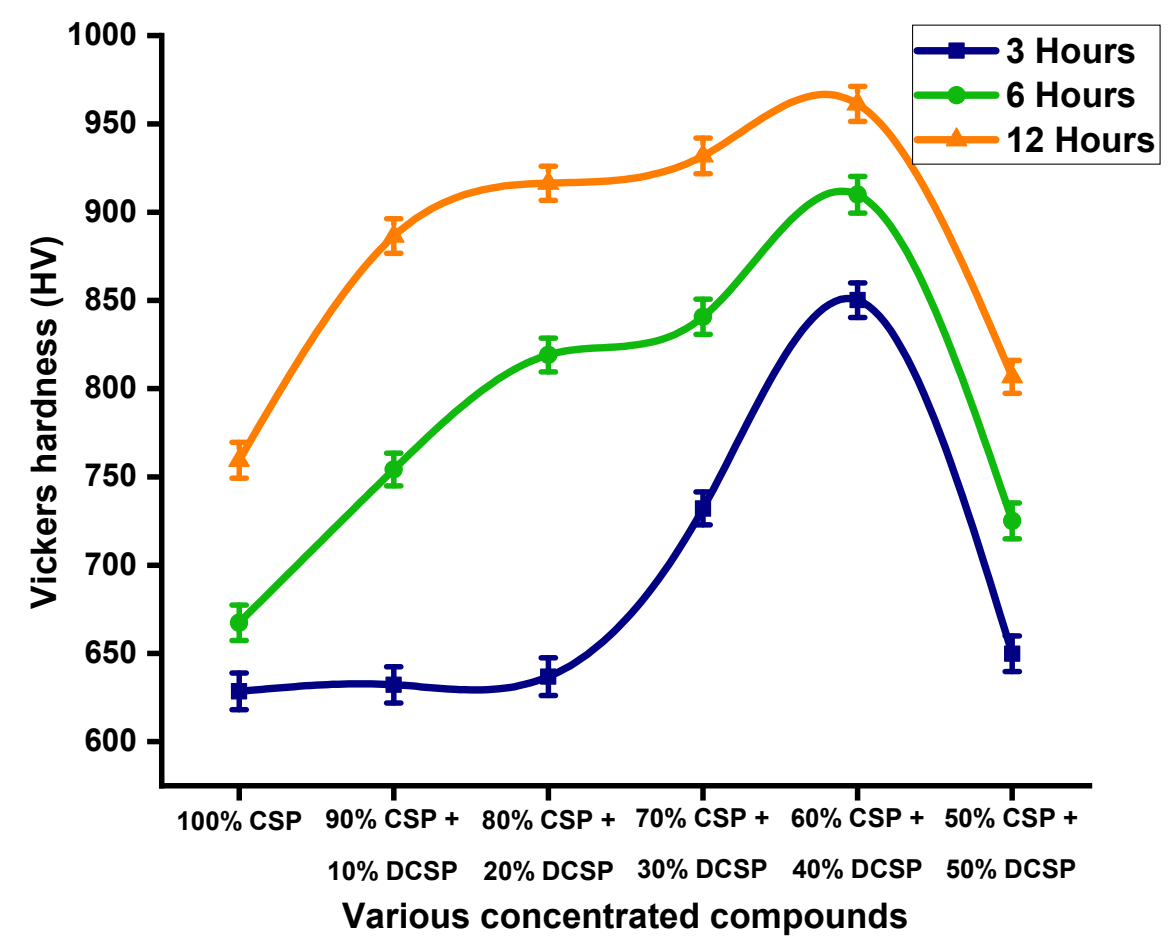

Figure 10. Surface hardness of quenched SCM 420 steel specimens prepared with various CSP:DCSP ratios and carburizing times. 


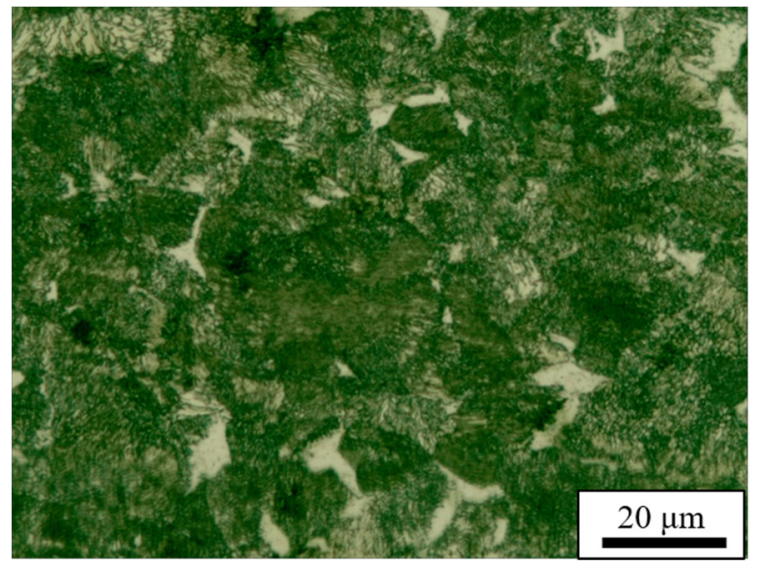

(a)

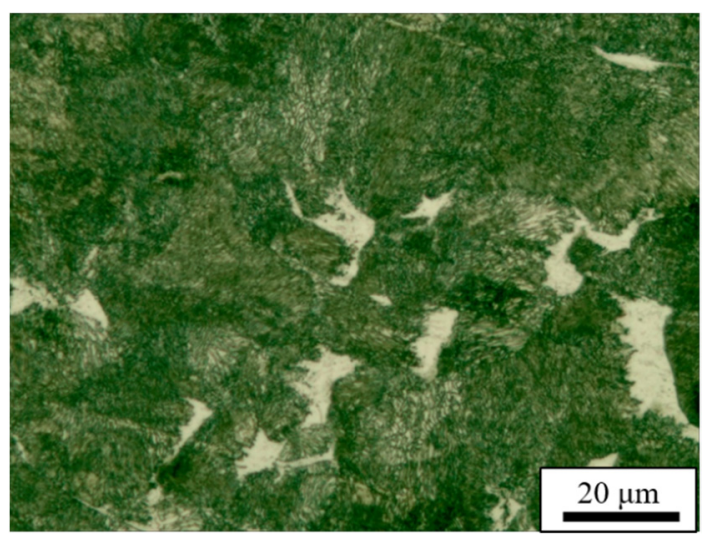

(b)

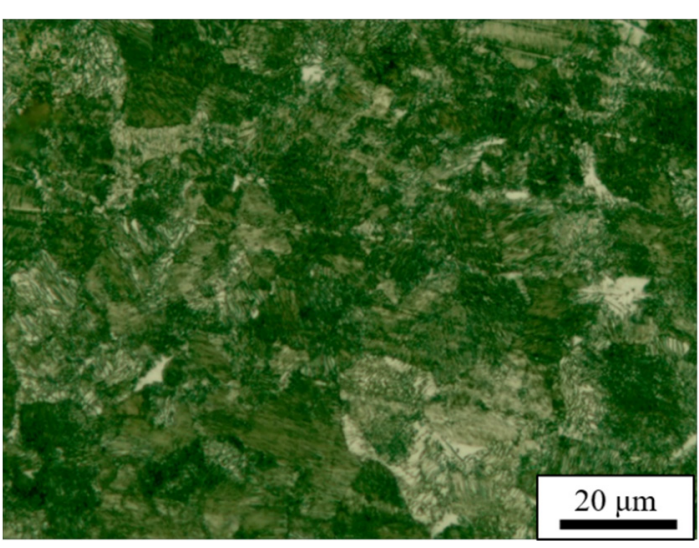

(c)

Figure 11. Microstructures of SCM 420 carburized specimens prepared with a CSP/DCSP ratio of 60\%:40\% and carburizing times of: (a) $3 \mathrm{~h}$ "Reprinted from [31] under the CC BY license", (b) 6 h, and (c) $12 \mathrm{~h}$.

\subsection{Microhardness Profiles of Carburized and Quenched SCM 420 Specimens}

Figure 12 shows the microhardness profiles of the quenched SCM 420 specimens prepared with various CSP:DCSP ratios and a carburizing duration of $3 \mathrm{~h}$. For all of the samples, the hardness gradually decreased with an increasing distance from the surface and began to stabilize at a depth of approximately $1300 \mu \mathrm{m}$. For a longer carburizing time of $6 \mathrm{~h}$, the diffusion layer thickness increased to $2300 \mu \mathrm{m}$, as shown in Figure 13. Moreover, for the maximum carburizing time of $12 \mathrm{~h}$, the diffusion layer thickness increased significantly to $3300 \mu \mathrm{m}$, as shown in Figure 14. In other words, the diffusion layer thickness increased by around 2.5 times as the carburizing duration increased from $3 \mathrm{~h}$ to $12 \mathrm{~h}$.

Figure 15 shows the carbon content distribution within the diffusion layer of the quenched specimen prepared with a CSP:DCSP ratio of 60\%:40\% and carburizing times of 6 and $12 \mathrm{~h}$. For a carburizing time of $6 \mathrm{~h}$, the maximum carbon content of $0.906 \pm 0.008 \mathrm{wt} \%$ in the surface gradually reduced with an increasing depth and approached a constant value of approximately $0.224 \pm 0.006 \mathrm{wt} \%$ at a depth of $2300 \mu \mathrm{m}$. After extending the carburizing time to $12 \mathrm{~h}$, the carbon content gradually decreased from $1.14 \pm 0.007 \mathrm{wt} \%$ at the surface to $0.225 \pm 0.006 \mathrm{wt} \%$ at a distance of $3300 \mu \mathrm{m}$ toward the center. In general, the results confirmed that the carburizing time has a critical effect on the carburized layer thickness of pack-carburized SCM 420 steel. Figure 16a-c present OM images of the quenched specimens prepared with a CSP:DCSP ratio of $60 \%: 40 \%$ and carburizing times of 3, 6 , and $12 \mathrm{~h}$, respectively. Again, the results confirmed that the depth of the carburized layer increases with an increasing carburizing time. In order to compare the wear resistance of the samples, pin-on-disk wear tests were performed with a load of $20 \mathrm{~N}$ and a distance of $200 \mathrm{~m}$. Figure 17 shows that the weight loss value for SCM 420 original raw material (i.e., 
non-carburized) of $2.8 \mathrm{mg}$. The quenched specimen prepared with a CSP:DCSP ratio of 60\%:40\% and a carburizing time of $12 \mathrm{~h}$ obtained a weight loss value of $1.1 \mathrm{mg}$. This result indicates that the wear resistance of SCM 420 steel increases after the carburization process.

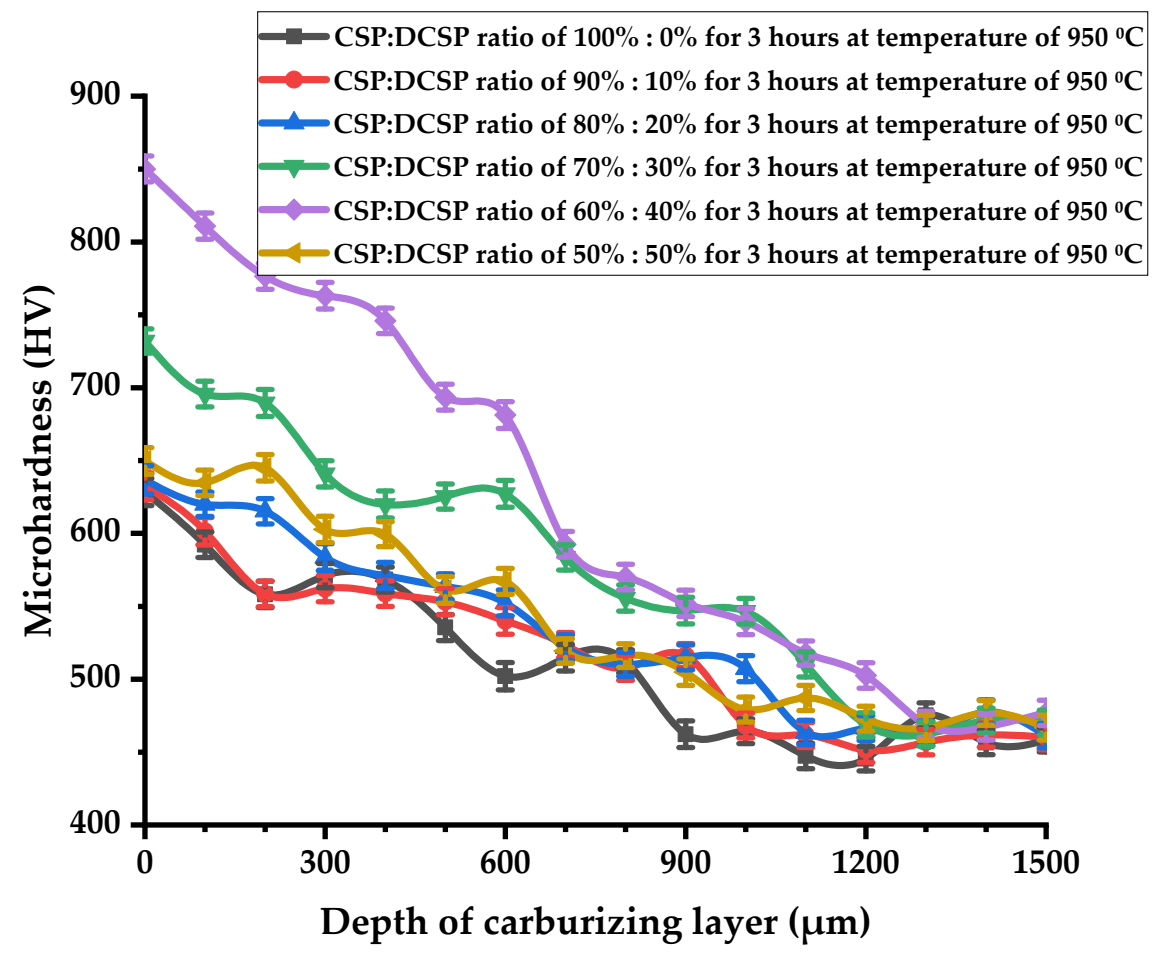

Figure 12. Microhardness profiles of SCM 420 quenched specimens prepared with various CSP:DCSP concentrations and a carburizing duration of $3 \mathrm{~h}$. "Reprinted from [31] under the CC BY license".

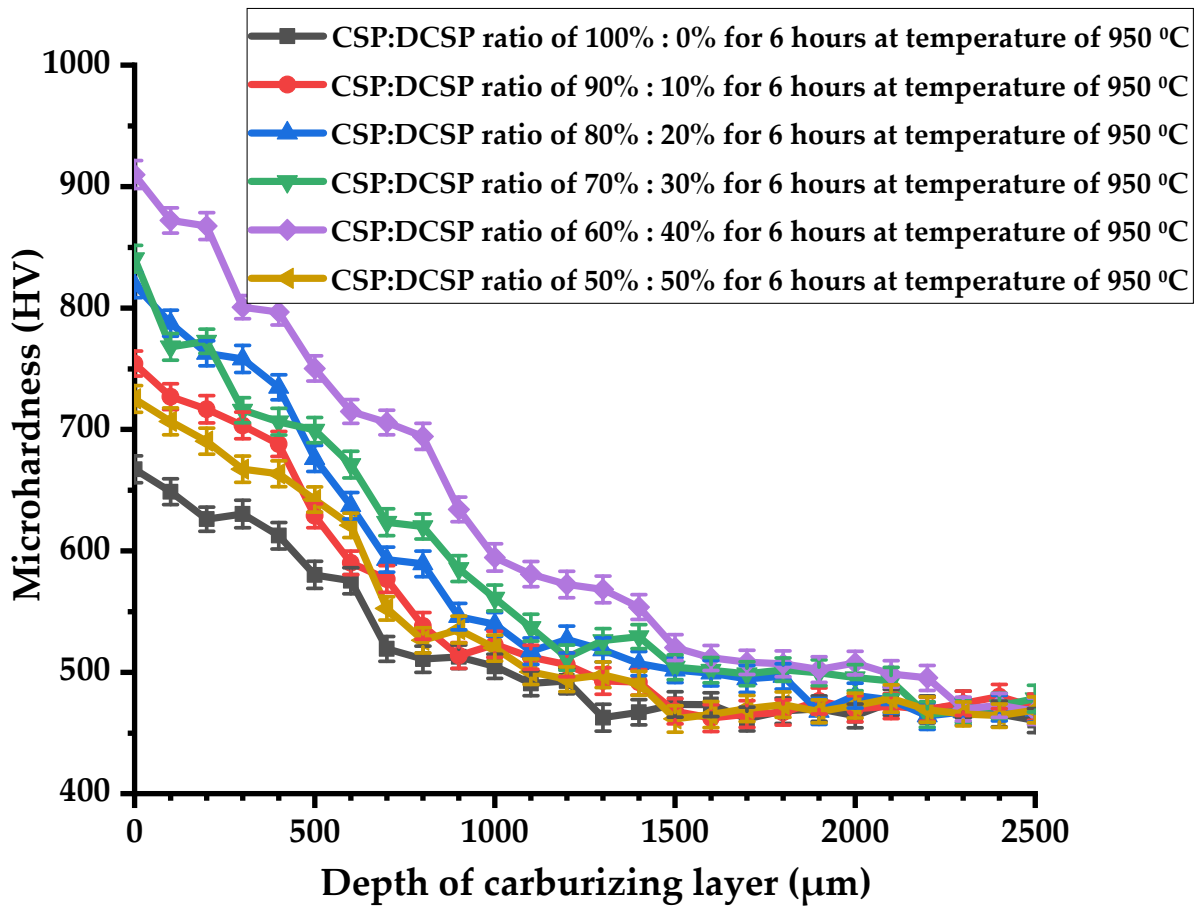

Figure 13. Microhardness profiles of SCM 420 quenched specimens prepared with various CSP:DCSP concentrations and a carburizing duration of $6 \mathrm{~h}$. 


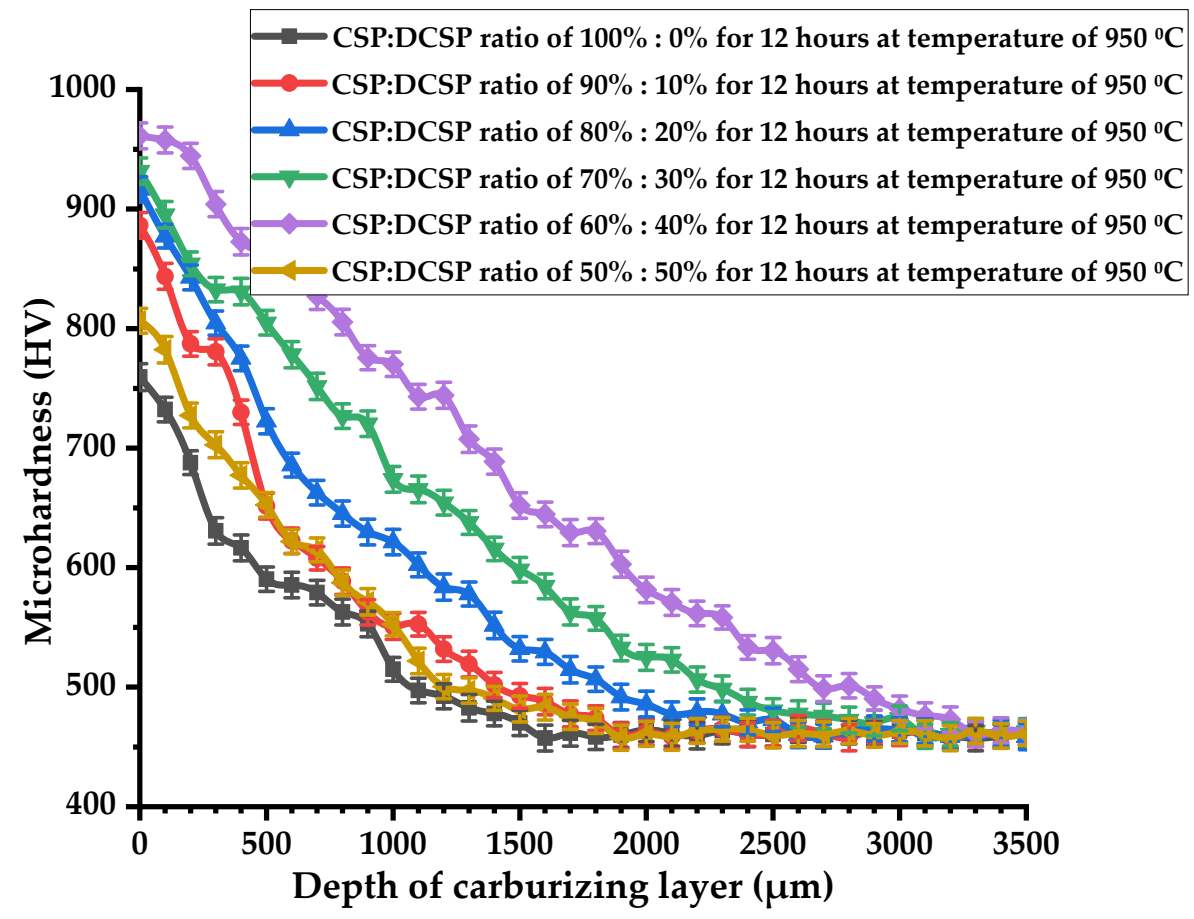

Figure 14. Microhardness profiles of SCM 420 quenched specimens prepared with various CSP:DCSP concentrations and a carburizing duration of $12 \mathrm{~h}$.

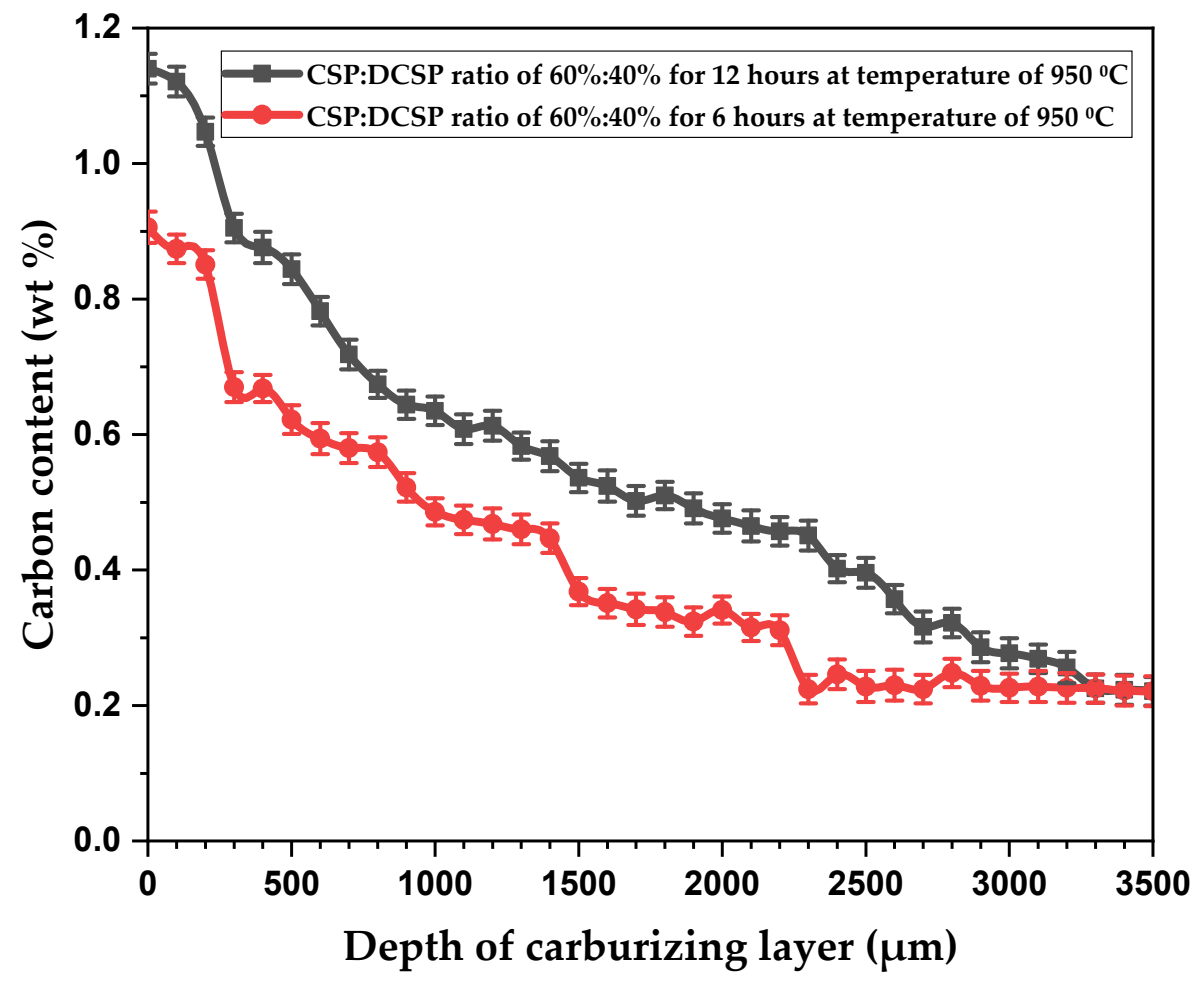

Figure 15. Carbon content distribution within the carburized layer of a quenched specimen prepared with a CSP:DCSP ratio of 60\%:40\% and carburizing durations of 6 and $12 \mathrm{~h}$. 


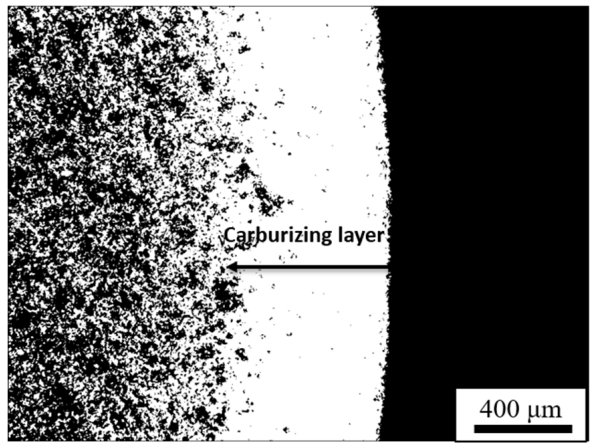

(a)

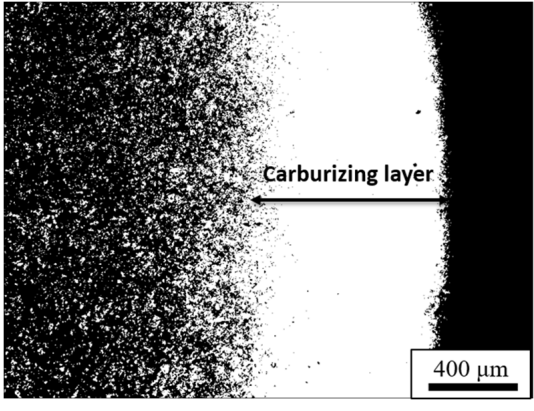

(b)

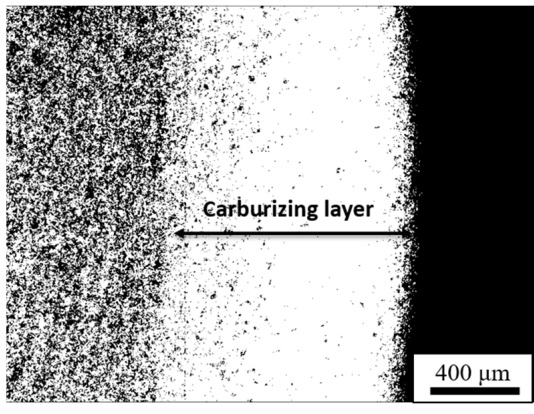

(c)

Figure 16. Microstructures of diffusion layers in SCM 420 quenched specimens prepared with a CSP/DCSP ratio of 60\%:40\% and carburizing times of: (a) $3 \mathrm{~h}$, (b) $6 \mathrm{~h}$, and (c) $12 \mathrm{~h}$.

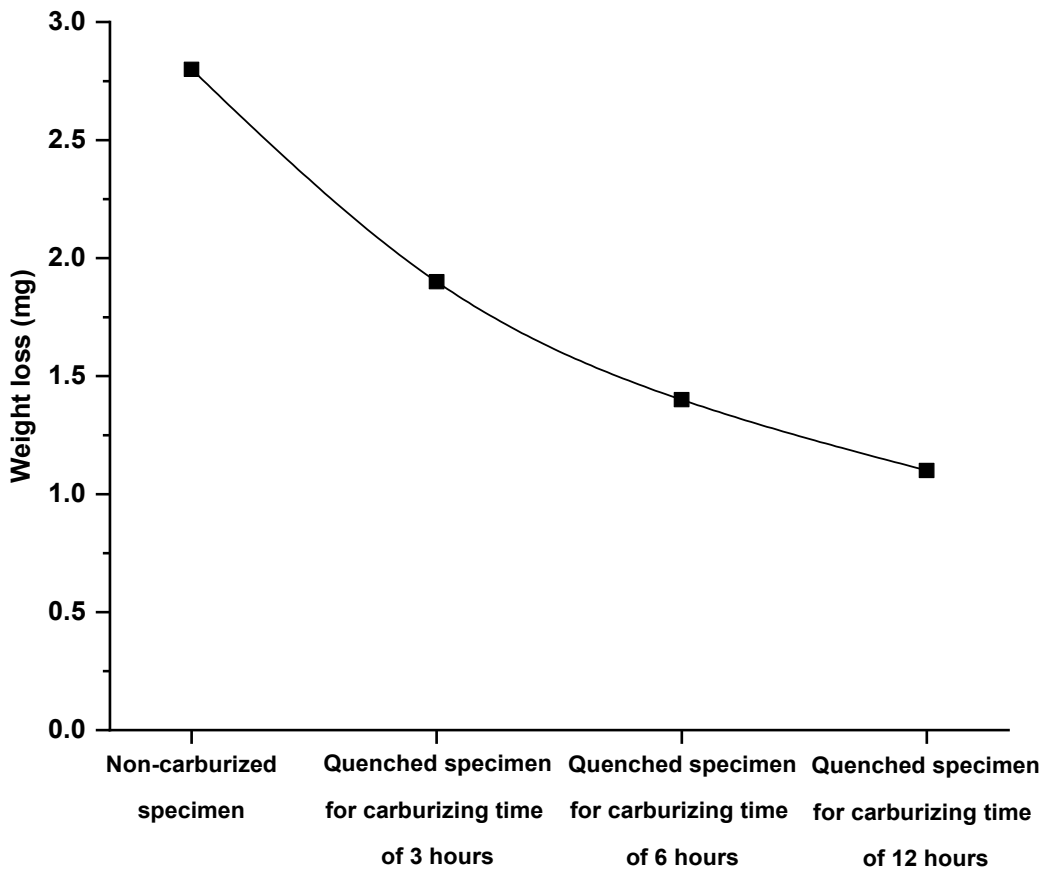

Figure 17. The wear test results of SCM 420 original raw material and quenched specimen carburized with CSP:DCSP ratio of $60 \%: 40 \%$.

\section{Conclusions}

This study investigated the viability of dog conch shell powder (DCSP) and coconut shell powder (CSP) as carburizing media for the pack carburization of SCM 420 steel at a temperature of $950{ }^{\circ} \mathrm{C}$. The investigation considered both as-carburized and as-quenched samples and focused particularly on the effects of the CSP:DCSP ratio (100\%:0\%, 90\%:10\%, 
$80 \%: 20 \%, 70 \%: 30 \%, 60 \%: 40 \%$, and 50\%:50\%) and carburizing time (3, 6 , and $12 \mathrm{~h})$ on the microstructure, carbon content, and microhardness of the samples. The results showed that the optimum carburizing performance, i.e., the highest carbon content and surface hardness, was achieved using a CSP:DCSP ratio of 60\%:40\%, and was associated with increased stability of the $\mathrm{CaCO}_{3}$ phase. It was also shown that the carbon content and surface hardness increased with an increasing carburizing time. For the as-carburized samples, the maximum carbon content was around $1.14 \pm 0.007 \mathrm{wt} \%$, while the maximum surface hardness was $604.9 \pm 4.674 \mathrm{HV}$. However, the quenching process increased the maximum surface hardness to around $961.3 \pm 4.918 \mathrm{HV}$ and resulted in the formation of a carburized layer with a thickness of around $1300 \mu \mathrm{m}$ given a carburizing time of $3 \mathrm{~h}$. The thickness of the carburized layer increased by around 2.5 times as the carburizing time was increased to $12 \mathrm{~h}$. Additionally, the wear property of SCM 420 steel-carburized specimens was promoted, as the wear resistance of SCM 420 steel increased after carburization. Future studies will examine the wear resistance, impact strength, and fatigue resistance of SCM 420 carburized specimens in detail to complete the mechanical properties characterization.

Author Contributions: Conceptualization, R. and C.-C.W.; methodology, R. and C.-C.W.; software, R. and A.S.; formal analysis, R. and C.-C.W.; investigation, R. and C.-C.W.; data curation, R., C.-C.W. and A.S.; writing - original draft preparation, R., and A.S.; writing-review and editing, R., C.-C.W. and A.S.; visualization, R. and C.-C.W. All authors have read and agreed to the published version of the manuscript.

Funding: This research was funded by the Ministry of Science and Technology, Taiwan R.O.C., under grant No. MOST 110-2622-E-218-002.

Institutional Review Board Statement: Not applicable.

Informed Consent Statement: Not applicable.

Conflicts of Interest: The authors declare no conflict of interest.

\section{References}

1. Kong, J.H.; Okumiya, M.; Tsunekawa, Y.; Takeda, T.; Yun, K.Y.; Yoshida, M.; Kim, S.G. Surface Modification of SCM420 Steel by Plasma Electrolytic Treatment. Surf. Coat. Technol. 2013, 232, 275-282. [CrossRef]

2. Kazuaki, F.; Kunikazu, T.; Tetsuo, S. Examination of Surface Hardening Process for Dual Phase Steel and Improvement of Gear Properties. JFE GIHO 2009, 23, 24-29.

3. Jeong, Y.E.; Lee, J.Y.; Lee, E.K.; Shim, D.S. Microstructures and Mechanical Properties of Deposited Fe-8Cr-3V-2Mo-2W on SCM420 Substrate Using Directed Energy Deposition and Effect of Post-Heat Treatment. Materials 2021, 14, 1231. [CrossRef] [PubMed]

4. Natpukkana, P.; Pakinsee, S.; Boonmapat, S.; Mitsomwang, P.; Borrisutthekul, R.; Panuwannakorn, R.; Khoa-phong, L. Investigation of Notch Shear Cutting for JIS SCM420 Steel Wire Rod. IOP Conf. Ser. Mater. Sci. Eng. 2018, 436, 012013. [CrossRef]

5. Chang, Y.-P.; Wang, H.-Y.; Chou, H.-M. A Novel Application on the Drive Elements of Using Electrical Contact Resistance and Friction Coefficient for Evaluating Induction Heat Treatment. Materials 2021, 14, 865. [CrossRef] [PubMed]

6. Drozd, K.; Walczak, M.; Szala, M.; Gancarczyk, K. Tribological Behavior of AlCrSiN-Coated Tool Steel K340 Versus Popular Tool Steel Grades. Materials 2020, 13, 4895. [CrossRef] [PubMed]

7. Li, G.; Li, C.; Xing, Z.; Wang, H.; Huang, Y.; Guo, W.; Liu, H. Study of the Catalytic Strengthening of a Vacuum Carburized Layer on Alloy Steel by Rare Earth Pre-Implantation. Materials 2019, 12, 3420. [CrossRef]

8. Raja, M.A.; Mishra, M.R. A Study of Optimization and Improvement of Mechanical Properties of Low Carbon Steel by the Process of Carburization. Int. J. Eng. Tech. Res. IJETR 2019, 9, 2454-4698. [CrossRef]

9. Prime, M.B.; Prantil, V.C.; Rangaswamy, P.; García, F.P. Residual Stress Measurement and Prediction in a Hardened Steel Ring. Mater. Sci. Forum 2000, 347, 223-228. [CrossRef]

10. Oyetunji, A.; Adeosun, S.O. Effects of Carburizing Process Variables on Mechanical and Chemical Properties of Carburized Mild Steel. J. Basic Appl. Sci. 2012, 8, 319-324. [CrossRef]

11. Levitas, V.I.; Roy, A.M.; Preston, D.L. Multiple Twinning and Variant-Variant Transformations in Martensite: Phase-Field Approach. Phys. Rev. B 2013, 88, 54113. [CrossRef]

12. Levitas, V.I.; Roy, A.M. Multiphase Phase Field Theory for Temperature- and Stress-Induced Phase Transformations. Phys. Rev. B 2015, 91, 174109. [CrossRef]

13. Benarioua, Y. Effect of Temperature and Time of Carburizing Treatment on the Structure and the Hardness of Steel 20MC4. Int. J. Sustain. Water Environ. Syst. 2016, 8, 3-6.

14. Madu, K.; Uyaelumuo, A.E. Parametric Effects of Carburization Time and Temperature on the Mechanical Properties of Carburized Mild Steel. SSRN Electron. J. 2018, 1, 1-7. [CrossRef] 
15. Aramide, F.O.; Ibitoye, S.A.; Oladele, I.O.; Borode, J.O. Effects of Carburization Time and Temperature on the Mechanical Properties of Carburized Mild Steel, Using Activated Carbon as Carburizer. Mater. Res. 2009, 12, 483-487. [CrossRef]

16. Abdulrazzaq, D.M.A. Investigation the Mechanical Properties of Carburized Low Carbon Steel. Int. J. Eng. Res. Appl. 2016, 6, 59-64.

17. Ahamad, N.W.; Jauhari, I.; Azis, S.A.A.; Aziz, N.H.A. Surface Properties and Activation Energy of Superplastically Carburized Duplex Stainless Steel. Mater. Chem. Phys. 2010, 122, 454-458. [CrossRef]

18. Singh, R. Investigation of Optimal Process Parameters for Mechanical and Wear Properties of Carburized Mild Steel Using Taguchi Approach. Int. J. Eng. Sci. Adv. Res. 2015, 1, 90-92.

19. Asrofi, M.; Hidayatulloh, M.A.; Jatisukamto, G.; Sutjahjono, H.; Sakura, R.R. The Effect of Temperature and Volume Fraction of Mahoni (Swietenia Mahogani) Wood Charcoal on SS400 Steel Using Pack Carburizing Method: Study of Hardness and Microstructure Characteristics. AIMS Mater. Sci. 2020, 7, 354-363. [CrossRef]

20. Negara, D.N.K.P.; Muku, I.D.M.K.; Sugita, I.K.G.; Astika, I.M.; Mustika, I.W.; Prasetya, D.G.R. Hardness Distribution and Effective Case Depth of Low Carbon Steel after Pack Carburizing Process under Different Carburizer. Appl. Mech. Mater. 2015, 776, 201-207. [CrossRef]

21. Soenoko, R.; Siswanto, E.; Widodo, T.D. Influence of Reheating in Pack Carburizing Process with Bamboo Charcoal and Cow Bone Powder Media for Hardness Number and Impact Strength Low Carbon Steel. Int. J. Appl. Eng. Res. 2018, 13, $2078-2083$.

22. Umunakwe, R.; Okoye, O.C.; Madueke, C.I.; Komolafe, D.O. Effects of Carburization with Palm Kernel Shell/Coconut Shell Mixture on the Tensile Properties and Case Hardness of Low Carbon Steel. FUOYE J. Eng. Technol. 2017, 2, 101-105. [CrossRef]

23. Syahid, M.; Hayat, A.; Arief, S. Fatigue Strength Improvement of Low Carbon Steel through Carburizing Process with Coconut Shell Charcoal. IOP Conf. Ser. Mater. Sci. Eng. 2020, 875, 012064. [CrossRef]

24. Sebayang, M.D. ST37 Steel Carburization with Coconut Charcoal. J. Technomater. Phys. 2021, 3, 29-35. [CrossRef]

25. Hassan, K.S. Comparative of Wear Resistance of Low Carbon Steel Pack Carburizing Using Different Media. Int. J. Eng. Technol. 2015, 4, 71. [CrossRef]

26. Darmo, S.; Soenoko, R.; Siswanto, E.; Widodo, T.D. Study on Mechanical Properties of Pack Carburizing SS400 Steel with Energizer Pomacea Canalikulata Lamarck Shell Powder. Int. J. Mech. Eng. Technol. 2018, 9, 14-23.

27. Soenoko, R.; Siswanto, E.; Widodo, T.D. Study on Fatigue Strength of Pack Carburizing Steel SS400 with Alternative Carburizer Media of Pomacea Canalikulata Lamarck Shell Powder. Int. J. Appl. Eng. Res. 2018, 13, 8844-8849.

28. Aramide, F.O.; Ibitoye, S.A.; Oladele, I.O.; Borode, J.O. Pack Carburization of Mild Steel, Using Pulverized Bone as Carburizer: Optimizing Process Parameters. Leonardo Electron. J. Pract. Technol. 2010, 16, 1-12.

29. Negara, D.N.K.P.; Widiyarta, I.M. The Study on Mechanical Properties of Pack Carburized Low Carbon Steel Using BaCO 3 as Energizer. IOP Conf. Ser. Mater. Sci. Eng. 2019, 673, 012125. [CrossRef]

30. Rajaguguk, T.O.; Sumardi, S. The Study of Low Carbon Steel Pack Carburizing Using Cow Bone and Coconut Shell. IOP Conf. Ser. Mater. Sci. Eng. 2019, 478, 012037. [CrossRef]

31. Ramli; Wu, C.-C. Novel Study on Mechanical Properties of Pack Carburizing SCM 420 Steel with Energizer Dog Conch. Int. J. Mod. Phys. B 2021, 35, 2150065. [CrossRef]

32. Demir, M.; Kahveci, Z.; Aksoy, B.; Palapati, N.K.R.; Subramanian, A.; Cullinan, H.T.; El-Kaderi, H.M.; Harris, C.T.; Gupta, R.B. Graphitic Biocarbon from Metal-Catalyzed Hydrothermal Carbonization of Lignin. Ind. Eng. Chem. Res. 2015, 54, 10731-10739. [CrossRef]

33. Wang, S.-C. Fine Activated Carbon from Rubber Fruit Shell Prepared by Using $\mathrm{ZnCl}_{2}$ and $\mathrm{KOH}$ Activation. Appl. Sci. 2021, 11, 3994. [CrossRef]

34. Bharatham, H.; Zakaria, M.Z.A.B.; Perimal, E.K.; Yusof, L.M.; Hamid, M. Mineral and Physiochemical Evaluation of Cockle Shell (Anadara granosa) and Other Selected Molluscan Shell as Potential Biomaterials. Sains Malays. 2014, 43, $1023-1029$. 